\title{
A Systematic Approach to the Understanding of National Security in the Legal Dimension
}

\author{
Denis V. Iroshnikov ${ }^{1}$ \\ ${ }^{1}$ Department of «Theory of Law and Natural Resource Law», Russian University of Transport, Russia \\ Correspondence: Denis V. Iroshnikov, Department of «Theory of Law and Natural Resource Law», Russian \\ University of Transport, Russia. Tel: 791-0616-0909. E-mail: dv-iroshnikov@mail.ru
}

Received: September 22, 2018

Accepted: October 6, $2018 \quad$ Online Published: October 17, 2018

doi:10.5539/jpl.v11n4p11

URL: https://doi.org/10.5539/jpl.v11n4p11

The research has been undertaken with the financial support of the Russian Foundation for Basic Research as part of the scientific project № 17-03-00767 "Security as a Legal Category".

\begin{abstract}
Nowadays, security issues are critically burning for the world community, the State and society as well as for an individual. Practical activities of states and other structures which ensure national security in general and its certain types in particular must be based on a comprehensive scientific study of such category as "national security" primarily from the philosopho-legal point of view. This is particularly reflected in the development of the science of security (SoS). This article presents a comprehensive fundamental philosopho-legal study of the national security system. The category "national security" is multidimensional and includes such types as state security, public security, personal security, information security, environmental security, transport security and others. In the article there is an attempt to reconsider the category of "national security" from the point of view of a systematic approach to the analysis of the basis of differentiation of certain types in its system. The study is aimed at understanding the essence, nature and characteristics of national security. The results of this study can be used in public administration and legal confirmation of political decisions. The author comes to the conclusion that it is possible to distinguish national security into types in terms of $1-$ a security object (interest to be protected) which therefore is divided into "social" (primary) and "non-social" (secondary) and in terms of 2 - a source of a threat.
\end{abstract}

Keywords: national security, system of national security, types of national security, state security, public security, personal security

\section{Introduction}

One of the most important theoretical and legal aspects in the general theory of national security is the system of national security. Nowadays the variety of types in the category of "national security" cannot help reveal the system of these types comprehensively. A bare listing of them is also very difficult within the exhaustive list.

Under the system of national security, we propose to understand collectively types and subtypes of national security in their interaction. It is necessary to know the difference between the concepts of a "national security system" and a "national security organization". In the latter, among other things, a system of forces, means of support and other components must be included.

Today the doctrine distinguishes a huge number of types of safety, including very specific ones and as a rule without any reflection in normative documents (for example, "mental security").

In this regard, it seems appropriate to study a national security system based on those types of security that are represented in the system of current legislation.

There are a lot of these types. They are state security, public security, personal security, information security, environmental security, economic security, food security, fire safety, transport security and others.

In this research, we start from the thesis that law and security are inextricably linked and that one of the most important aspects of national security and its study is the legal aspect. Today security permeates all spheres of public life. Law is a universal regulator of social relations which guarantees a certain stability in society and its 
sustainable development (Fischhendler \& Katz, 2013). Therefore, when we talk about the national security system, we imply considering it in the legal context.

The analysis of the legislation of different countries has shown that the issues of a particular type of national security are not equally represented by the volume of legal confirmation. Some types are regulated by separate legal acts and others might only be mentioned in the regulations. This is primarily due to the importance of certain types of security at this period of time for the State and society as well as due to the volume of security relations in certain areas.

However, this does not diminish the importance of the study of national security from the standpoint of a systematic approach and the development of criteria for the classification of its types.

\section{Method}

The study is based on the following methodological principles:

1) The principle of consistency and complexity. This principle will help comprehensively study the security relations in their philosophical and legal dimension.

2) The principle of unity of theory and practice. With regard to this principle the developed theoretical foundations will help develop practical recommendations for improving the existing system of national security.

3) The principle of objectivity of a study. This principle will help conduct the study without taking into account any subjective factors that may adversely affect its results.

The main method of research is a systematic approach, according to which national security is considered as a system of interrelated elements and as interconnections inherent to its elements. In addition, the research is based on a historical method which helps show the historical evolution of different approaches to the understanding of security as an object of the scientific research.

\section{Results and Discussion}

Over the past decade, significant efforts have been made to develop the "Science of Security" (SoS) which is the subject of dozens of scientific articles. Thus, according to C. Herley and P. van Oorschot, "science" is the best and only way to study security (Herley \& Van Oorschot, 2018). Nowadays it is also necessary to apply an interdisciplinary systematic approach for the development of the general theory of the science of security (Geysen \& Verbruggen, 2003) taking into account the complexity of the concept of "security". However, one legal science does not provide sufficient understanding of the comprehensive theoretical issue of legal security issues (Milosavljević, 2014). The security paradigm includes not only legal, political and military, but also sociological, cultural and other aspects, the philosophical side of understanding of the phenomenon of security at most. Even information security which until recently has been developing rapidly along with the computer technology in its special "extra-scientific" way, according to researchers, also demands a scientific approach nowadays (Longstaff et al., 2010).

Herewith, the development of the science of security is gradual, and it takes place not in all countries or on all continents. In Russia, for example, security issues are actively studied in terms of philosophy, political science, law, sociology, history of economics and other social sciences. At the same time a separate branch of social sciences - the "Science of Security" is not distinguished. In Poland, however, there was a transformation of military science into two separate disciplines: Science of Security and Defense Science. Along with the ongoing debates or theoretical and ontological aspects of both, according to the famous Polish expert in the field of methodology of security sciences A. Glen, such separation has led researchers to almost a scientific revolution in this sphere (Glen, 2012).

Due to the topicality of this study, we should agree with the opinion of N.I. Kostyuchenko that today the national security system has almost not been investigated from the point of view of a systematic approach (Kostyuchenko, 2017). Such approach should help open the borders for further scientific research on various types of national security.

There is also another more complex issue arising with the seemingly simple issue of dividing national security into types depending on spheres of human activity, such as to what kind of security we shall refer complex types, for example, "environmental security in transport" or "information security of a person". In this regard, the main issue arises on the criteria for the distinction of national security by type.

It is interesting to determine the general theoretical scientifically based criteria for the distinction of security by type that may be used as a basis for the development a national security system. 
At the same time, these criteria must necessarily have the following important features:

1) Logic (not to contradict the laws of formal logic);

2) Universality (to be applicable to any type of national security);

3) Objectivity (not to base on subjective attitudes).

Way back Hans Kelsen wrote that the statements by which a scientist described and explained the object of his research should not depend on his own values (Kelsen, 1951).

The research has identified and justified the following criteria for the definition of types of national security.

\subsection{The Distinction of Security by Types of the Security (the Interest to Be Protected)}

Since the end of the Cold War personal security has become an important approach in international politics, law and political science. In contrast to the so-called "Westphalian state system" which recognizes states only as objects of security. Since then personal security has become a central category in discussions on security policy and law (Zwierlein \& Graf, 2010).

The modern extended understanding of national security is a synthesis of security of citizens and state security, as well as a contribution of the State to international and global security (Mijalković \& Milošević, 2011).

In this regard, in our opinion, the types of national security should include state security, public security and personal security. At the same time within the scope of personal security it is possible to distinguish subtypes depending on the social or professional status of an individual (for example, "security of children"; "security of judges").

We suggest to consider an individual, society and the State as social objects of national security. In other words, they are people and their associations in the form of society and the State with their own vital interests. These objects of national security can be called primary objects.

Adding to that, from the point of view of the systematic approach, society and the State may be considered as unique systems to ensure security of an individual. Speaking about the philosophical aspect of understanding of public security, we shall refer to the works of the famous Russian researcher of security problems A. A. Prokhozhev. It should be noted that society itself as a system is already a kind of a security mechanism since "the desire for security has been one of the motivating reasons for the unification of ancient people into a society". The same thesis may be referred to the State. To support this statement, T. Hobbes in his treatise "Leviathan" wrote that the main goal of the State is to ensure security (Hobbes, 1651).

Speaking of the correlation between personal security and social security, it is necessary to review the category of "collective security". Security risks aimed at the security of a person one way or another threaten public security. Meanwhile, the public is not an independent entity (substance). Therefore, the concept of collective security cannot arise separately from security of people representing a community (Stolarski, 2012).

However, there is also an opposite situation when interests of society are opposed to personal interests. At this point, we have two models: either interests of an individual or interests of a society come to the first place, whereas an individual, in turn, sacrifices his/her interests for the sake of a common goal. These models of "a personal interest priority" and "a public interest priority" in different variations are presented in the legislation and policies of different countries.

For the successful existence of primary (social) security objects, such as a personality of society and the State, some systems are needed to ensure this process - economic, environmental, informational, transport, energy and other kinds of systems. The security of such systems (spheres of activity) is a condition for security of social objects.

These systems may be considered as non-social (secondary) security objects. In view of the fact that there is a vast variety of human activities, each of these types of security may include subtypes. For example, economic security includes food security.

In addition, each social object (an individual, society or the State) has a specific interest in a certain non-social sphere.

The term "interest" itself can be understood from three perspectives: axiological - something is of interest, because it is a value in a given system of axes (Van Dyke, 1962); from the perspective of the needs - if a subject needs something, this is his/her interest (Flathman, 1966; Held, 1970); from the teleological perspective - when an achievement of a goal is more important for a subject in comparison to "participation in the distribution of available goods in a certain group" (Mucha, 1982). 
Thus, such types of security emerge when there is a social object and his/her interest in a non-social environment. This is, for example, "economic security of an individual", "information security of the State", etc. (Figure 1).

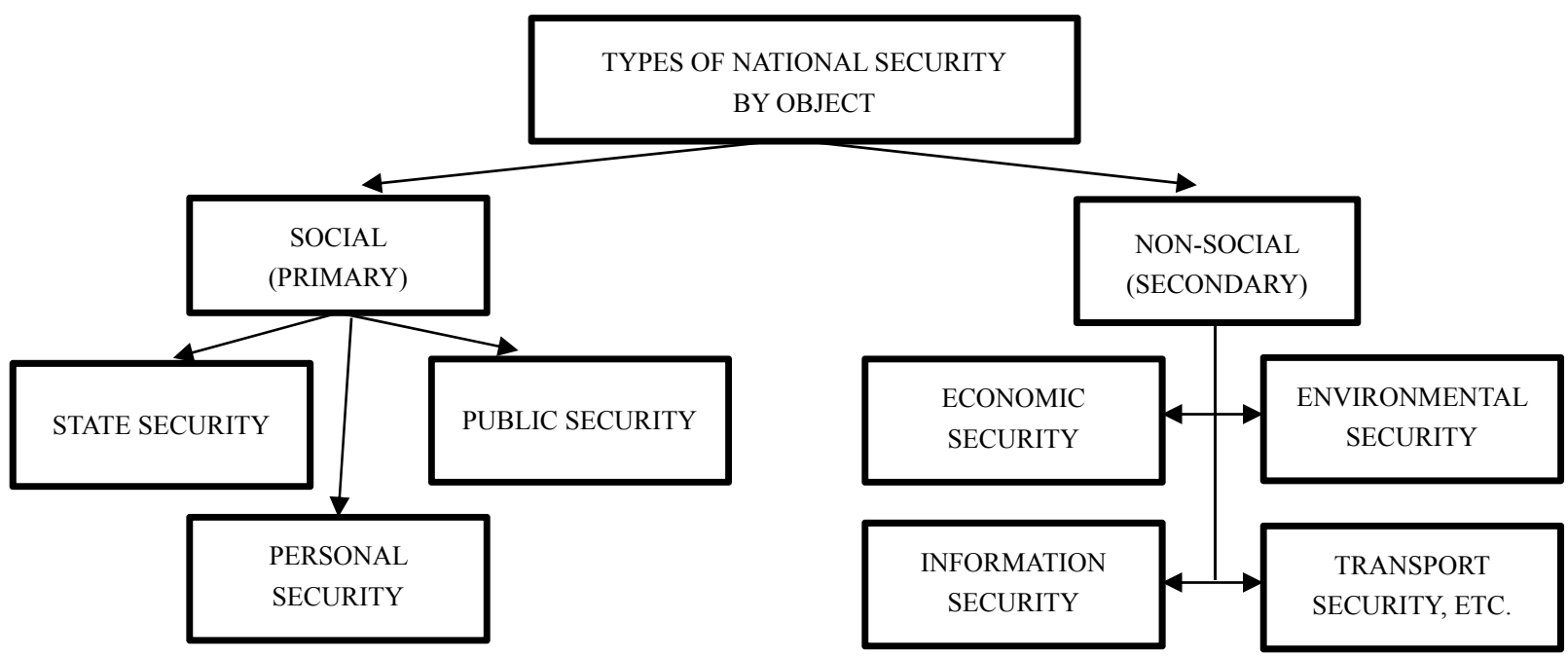

Figure 1. Types of national security by object

\subsection{The Distinction of Security by Types in Accordance with Sources of Threats}

The above distinction of national security by the object (protected interest) cannot cover all existing types and subtypes of national security. An additional criterion for the classification of security types is proposed in this research, i.e. a source of threats.

The classic examples of such types of security are fire safety, radiation security, chemical safety, nuclear security, etc. Such distinction is fundamentally different from the distinction depending on the protected interest (for example, in the case of fire safety, we do not protect "fire", we protect from "fire"). At the same time the object of protection is mostly often a society (Figure 2).

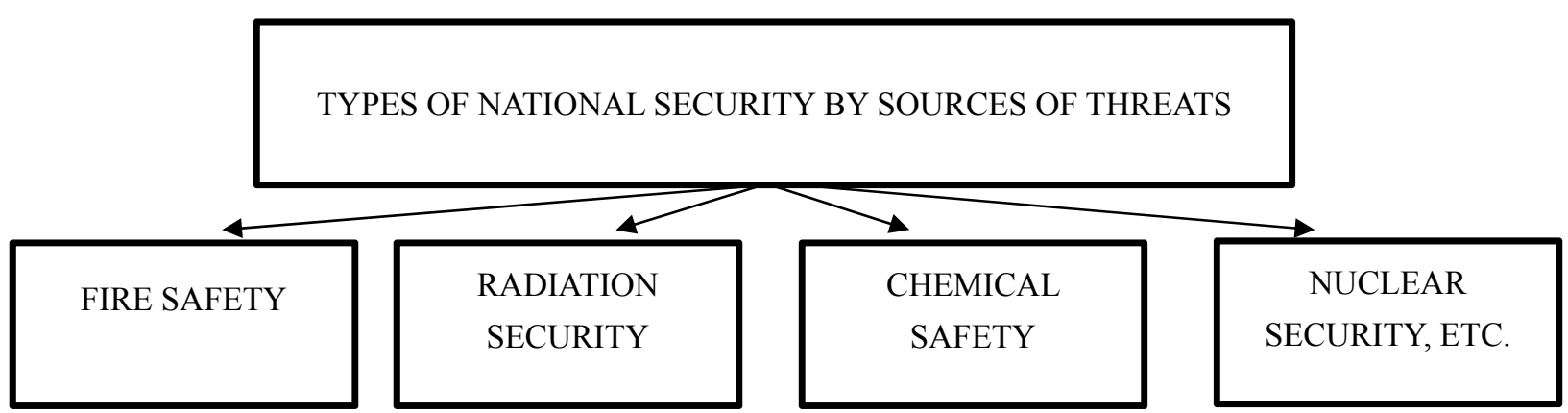

Figure 2. Types of national security by sources of threats

As for this classification, two types of security may be confused. One of them is an object and another one is a threat.

For example, environmental security in transport. In this case, the environmental system is an object of security and transport is a source of an economic threat.

Sometimes same names of types of security by object may be presented as types of security by sources of threats. For example, "public transport security" should be distinguished. In this case transport (as distinguished from transport security) is presented as a source of a threat to people. Another example is "information security for children" when information (as distinguished from information security) is not an object, but is a source of a threat as well. As far as this issue is concerned, B. Milosavljević has reviewed legal texts and has come up with a huge variety of narrow terms on road-traffic safety, which is differentiated for the purpose of security in certain types of traffic (traffic on roads, rail, sea, river and air), and then to terms on security of people: traffic, participants of traffic and vehicles (Milosavljević, 2014). 
The results of the research were discussed at the IV International Scientific and Practical Conference from the series "Poland-Russia" on the topic "Integration or Disintegration of the Modern International Environment" at the Siedlce University of Natural Sciences and Humanities (Poland) (November 9-10, 2017) and at the VI International Scientific and Practical Conference "Transformation Processes in the Field of Law, Regional Economics and Economic Policy: Current Economic, Political and Legal Problems" at the Baltic International Academy (Riga, Latvia) (December 8, 2017).

\section{Summary}

Scientifically grounded criteria for the differentiation of national security by types are proposed under the scope of the conducted research.

It is necessary to review the differentiation of security by types in accordance with the criterion of "a security object (interest to be protected)". Within this classification it is possible to distinguish safety of an individual, society and the State. These are social (primary) objects of security.

For the normal existence of the specified security objects it is necessary to have some systems which can make such process operational, such as an economic system, an ecological system, an informational system, transport infrastructure, an energy system and others. The security of these systems (spheres of activity) is a condition for security of social objects.

These systems may be considered as non-social (secondary) security objects. In this regard, we can distinguish economic security, environmental security, etc.

Additionally, each social object (an individual, society or the State) has a particular interest in a certain non-social sphere. Thus, there are such types of security which have their social object and their interest in a non-social environment. This is, for example, "economic security of an individual", "information security of the State".

It is also proposed to distinguish security by the criterion of "a source of a threat". In this regard, we can distinguish fire safety, radiation security, chemical safety, nuclear security, etc.

\section{Conclusion}

We believe that the criteria proposed in this article for the development of a national security system are logical, universal and objective to the extent that it is possible to talk about a scientifically grounded system of national security with its inherent inter-system interconnections with respect to each type and subtype.

The results of this research may be used when implementing the state legal policy for the enforcement of national security, including the improvement of the current legislation on national security.

\section{References}

Fischhendler, I., \& Katz, D. (2013). The use of "security" jargon in sustainable development discourse: Evidence from UN Commission on Sustainable Development. International Environmental Agreements: Politics, Law and Economics, 13(3), 321-342. https://doi.org/10.1007/s10784-012-9192-z

Flathman, R. (1966). The Public Interest. An Essay Concerning the Normative Discourse of Politics. New York-London-Sydney. pp. 15-16.

Geysen, W., \& Verbruggen, J. (2003). The Acceptance of Systemic Thinking in Various Fields of Technology and Consequences on the Respective Safety Philosophies. Human Factors and Ergonomics in Manufacturing, 13(3), 231-242. https://doi.org/10.1002/hfm.10037

Glen, A. (2012). Ontologiczne aspekty bezpieczeństwa wspótczesnego państwa - organizacji. Wspótczesne bezpieczeństwo polityczne. Warszawa - Siedlce, pp. 264-265.

Held, V. (1970). The Public Interest and Individual Interests. New York-London. p. 51.

Herley, C., \& Van Oorschot, P. (2018). Science of Security: Combining Theory and Measurement to Reflect the Observable. IEEE Security \& Privacy, 16(1), 12. https://doi.org/10.1109/MSP.2018.1331028

Hobbes, T. (1651). Leviathan, or, the Matter, Forme, \& Power of a Common-Wealth Ecclesiastical and Civil. Andrew Crooke, St. Paul's Churchyard, p. 86.

Kelsen, H. (1951). Science and politics. The American Political Science Review, XLV(3), 641. https://doi.org/10.2307/1951155

Kostyuchenko, N. I. (2017). Problems of the theory of national security associated with the uncertainty of the concept of "security" and its place in social systems. Bulletin of Krasnodar University of Russian MIA. No. 


\section{C. 35 .}

Longstaff, T., Balenson, D., \& Matties, M. (2010). Barriers to Science in Security. ACSAC '10 - Proceedings of the 26th Annual Computer Security Applications Conference. Austin, Texas, USA. - December 06 - 10. p. 127. https://doi.org/10.1145/1920261.1920281

Mijalković, S., \& Milošević, G. (2011). Correlation Between Economic, Corporate and National Security. Megatrend Review, 8(2), 438.

Milosavljević, B. (2014). Prilog teorijskopravnom određenju pojma bezbednosti. Pravni Zapisi, God. V, br. 1. p. 96.

Mucha, J. (1982). Konfliktowe modele społeczeństwa we współczesnej socjologii niemarksistowskiej - próba typologii. "Studia Socjologiczne" 1975, nr 1, Cit.ex: J. Drążkiewicz, Interesy a struktura społeczna, S. 28.

Prokhozhev, A. A. (2006). The theory of development and security of man and society. Moscow. C. 12.

Stolarski, G. (2012). Ontologiczny status kategorii bezpieczeństwa. Współczesne bezpieczeństwo polityczne. Warszawa - Siedlce, S. 276.

Van Dyke, V. (1962). Values and Interests. The American Political Science Review, 56(3), 567. https://doi.org/10.2307/1952490

Zwierlein, C., \& Graf, R. (2010). The Production of Human Security in Premodern and Contemporary History. Historical Social Research, 35(4), 7-8.

\section{Copyrights}

Copyright for this article is retained by the author(s), with first publication rights granted to the journal.

This is an open-access article distributed under the terms and conditions of the Creative Commons Attribution license (http://creativecommons.org/licenses/by/4.0/). 